\begin{tabular}{rr}
\hline çaḡdaş & Yaratıci Drama Dergisi 2018, 13(1), 1-17 \\
drama & www.yader.org \\
\hline
\end{tabular}

\title{
Yaratıcı Drama ve Absürd Tiyatro
}

\author{
Ömer Çetinkaya ${ }^{1}$ \\ Ömer Adıgüzel²
}

\begin{tabular}{lr}
\hline \multicolumn{2}{l}{ Makale Bilgisi } \\
\hline DOI: $10.21612 /$ yader.2018.001 \\
\hline \multicolumn{2}{l}{ Makale Geçmişi } \\
Geliş tarihi & 26.12 .2016 \\
Kabul & 25.07 .2017
\end{tabular}

Anahtar Sözcükler

Absürd tiyatro

Yaratıcı drama

\begin{abstract}
Öz
Bu çalışmada, Absürd Tiyatro'nun öğretiminde yaratıcı dramanın bir yöntem olarak kullanılmasının üniversite tiyatro topluluğu öğrencilerinin içerik bilgileri ile oyunculuk ve oyun yorumlama becerilerinin gelişimine etkilerini belirlemek amaçlanmıștır. Çalışmanin katılımcıları Ankara Üniversitesi Eğitim Bilimleri Fakültesi Tiyatro Topluluğu'nun üyesi olan 8 kadın ve 4 erkek toplam 12 öğrenciden oluşmaktadır. Tiyatro topluluğu ögrencileri, tiyatro çalışmaları kapsamında yaratıcı drama ile ilgili temel kavram ve uygulamalara ilişkin farkındalık düzeyine sahiptir. Bu çalışmada nicel ve nitel araştırma yöntemlerinin bir arada yer aldı ̆̆ karma yöntem kullanılmıştır. Veriler, açık uçlu sorulardan oluşan "Absürd Tiyatro" soru kâğıdı ve katılımcılarla gerçekleştirilen yarı yapılandırılmış görüşmeler aracılığıyla elde edilmiştir. Çalışma öncesinde ve sonrasında, katılımclların Absürd Tiyatro'ya ilişkin bilgi düzeyini belirlemek üzere "Absürd Tiyatro" soru kâğıdı kullanılarak katılımcıların çalışma öncesi ve sonrasındaki alan bilgisi düzeyleri arasındaki fark ortaya çıkarılmıştır. "Absürd Tiyatro" soru kâğıdında, akıma ilişkin iki, gelişime ilişkin iki, akımın temsilcilerine ilişkin bir soru yer almaktadır. Yaratıcı dramanın, katılımcıların oyunculuk becerisi ve oyunu anlamalarına etkisini belirlemek üzere katılımcılarla yarı yapılandırılmış görüş̧meler gerçekleştirilmiştir. Çalışma sonucunda tiyatro ile uygulamalı çalışmalar yapan üniversite ögrencilerinin yaratıcı drama yöntemiyle çalışılmasınin etkili ve verimli olduğu görülmüss, Absürd Tiyatro'nun eleştirel yanı ve yaratıcı dramanın sorgulatan yanının örtüştüğü, elde edilen bulgularda oyuncu ile oyun açısından olumlu sonuçların ortaya çıktığı belirlenmiştir.
\end{abstract}

\section{Creative Drama and Absurd Theatre}

\begin{tabular}{lr}
\hline Article Info \\
\hline DOI: $10.21612 /$ yader.2018.001 \\
\hline & \\
\hline Article History & \\
Received & 26.12 .2016 \\
Accepted & 25.07 .2017
\end{tabular}

Keywords
Absurd theatre
Creative drama

\section{Abstract}

In this study, it was aimed to determine the effects of using creative drama as a method in teaching of absurd theater to the content knowledge of the theater community students of university, acting and interpretation skills of the theater play. Participants of the study consist of 12 students, 8 female and 4 male students who are members of theater community in Ankara University Educational Sciences Faculty. The students of theater community has a level of awareness about basic concepts and practises related to creative drama within the scope of theater studies. This study used a mixed method in which quantitative and qualitative research methods coexisted. The datas were obtained through semi-structured interviews with participant "Absurd Theater" questionnaire consisting of open-ended questions. In before and after of this study, the "Absurd Theater" questionnaire that was used to determine participant's level of knowledge about the Absurd Theater, revealing the difference between participant's pre- and post-field knowledge levels. In the "Absurd Theater" question paper, there are two questions about current, two questions about development and there is a question about the represantives of current. Semi-structured interviews was done with participants to determine the impact of creative drama on acting skills and understanding the play. As a result of the study, it was determined that creative drama method was effective and productive for the students who studies practical with theater, questioning side of the creative drama and critical side of absurd theater overlapped, and that positive results were obtained in terms of the play and players in the obtained findings.

\footnotetext{
1 MEB Özel Doğaç Yaratıcı Drama Lideri/Eğitmeni, E-posta: omerctnky@hotmail.com

2 Prof.Dr., Ankara Eğitim Bilimleri Fakültesi Öğretim Üyesi, E-posta: omeradiguzel@gmail.com
} 


\section{Giriş}

Tiyatronun kaynağı, mağarada yaşayan insanların, avlarının başarısını kutlamak amacıyla toplanarak dans etmelerine ve olayların canlandırılmasına dayanır (Nutku, 1985; Brockett, 1993; Şener, 2012; Turani, 1971). İlkel insanların eylemleriyle bugünkü tiyatro anlayışı karşılaştırıldığında arada bir uçurum olduğu görülse de bu eylemler tiyatronun temel özelliklerini (eylem, -mış gibi yapma, rol oynama, topluca katılma vd...) barındırır (Doğan, 1995, s.21).

Tiyatro sanatı, ortaya çıkışından günümüze öz ve biçim bakımından değişiklikler geçirmiştir. Başlangıçta daha çok doğa olaylarını, hayvanları taklit etmek gibi eylemler görülür. Daha sonraları tiyatronun bütün toplumsal durumlardan etkilenerek geliştiği söylenebilir. Zamanla tiyatro iktidarı, toplumsal yapıyı eleştirmek için bir araç olarak ele alınmış, evrensel dünya görüşlerini içeren tiyatro oyunları yazılmış ve sahnelenmeye başlanmıştır (Piscator, 2012, s.22). Siyasal iktidarların, bir toplumun üretim biçiminin değişmesi (ilkel toplumdan feodalizme, feodalizmden kapitalizme geçmesi, değişmesi gibi), sanayi devrimi, makineleşme, bilgisayar devrimi gibi toplumsal olaylar tiyatronun da konusunu oluşturmuştur.

Kongar (1976, s.35)'a göre,

"Sergilenen her tiyatro yapıtı ya bir toplum kesiti ya bir toplumsal olay ya da bir duygu üzerinde anlatımlara ve soyutlamalara gider. Ister açıç̧a amaçlansın, isterse amaçlanmasın, her tiyatro olayl, toplumsal gerçeği daha iyi anlamamıza yardım eden bir toplum bilimsel model niteliği taşımaktadır. Ĕger toplumda herhangi bir değişim veya gelişim; dil değişikliği, iktidardan memnuniyetsizlik yabancılaşma vb. gibi birçok örneğini verebileceğimiz toplumsal olaylar veya olgular varsa, tiyatro bütün bunları konusu haline getirecektir ve çeşitli yönleriyle ve farklı karakterlerle bunu okura ve izleyiciye sunacaktır. Çünkü tiyatro toplumdan beslenen bir disiplindir.”

18. yüzyıl ortalarında "Sanayi Devrimi”nin ortaya çıkmasıyla, insanlık tarihinde önemli bir adım atılmıştır. Sanayi Devrimi’yle birlikte ortaya çıkan yeni buluşlar, insanların üretim için harcadıkları çabanın azalmasına (Tanilli, 2006, s.120), insanların üretim için harcadıkları çabanın azalması ise işsiz ve mutsuz bireylerin çoğalmasına neden olmuştur. İnsanlar alışkanlıklarından vazgeçmiş ve birbirleriyle olan ilişkilerinden kopmaya başlamışlardır.

Sanayi Devrimi’nin yalnızca küçük imalathaneleri değil tarımı da etkilemiş olması, el emeğinin yerine geçen makinelerin işe koşulması, boşta kalan el emeğinin hızla kente doğru göç etmesine neden olmuştur (Tanilli, 2006, s.121). Hazırlıksız olan kentlere yapılan göç, sağlıksız yerleşmelere neden olmuş ve insanların düşük ücretlerle çok uzun süre çalışmasını zorunlu kılmıştır. Bu durumu İpşiroğlu (1996, s.15) "Yeni bir insan türü çıkıyor ortaya: Topră̆ından, yaşadı̆̆ı çevreden, doğal bağlantılarından koparılarak yapay bir ortam içine itilmiş olan ve kitle içinde tek başına kalan insan, kitle-insanı" olarak betimler.

Sanayi Devrimi'nin bu dönemde ortaya çıkması ve gelişmesi, 20. yüzyılın ilk yarısında Birinci Dünya Savaşı ile şiddetini göstermeye başlamıştır. Sanayileşmiş ülkelerin üstünlük yarışının bu savaşta büyük rol oynadığı söylenebilir. Milyonlarca insanın ölümüyle sonuçlanan Birinci Dünya Savaşı toplumlarda derin izler bırakmış ve bu izler sanat eserlerine yansımıştır. Piscator "Politik Tiyatro" adlı kitabının başında şu sözlere yer verir ( 2012, s.1): 
“Takvimim 4 A ̈̆ustos 1914'te başllyor.

O günden itibaren barometre hızla yükselmeye başladı.

13 milyon ölü.

11 milyon sakat.

50 milyon asker cephede.

6 milyar tüfek.

50 milyar metreküp zehirli gaz."

Birinci Dünya Savaşının üzerinden çok zaman geçmeden, İtalya'da ve Almanya'da faşist yönetimlerin aktif olması, ekonomik bunalım içinde olan halkların savaşa sürüklenmesine neden olmuştur. $\mathrm{Bu}$ da birincisinden daha korkunç olan İkinci Dünya Savaşı'nı ortaya çıkarmıştır (Armaoğlu, 1984, s.258). İkinci Dünya Savaşı 7 milyonu Almanya'daki kamplarda olmak üzere, yaklaşık 50 milyon insanın ölümüyle sonuçlanmış; kullanılan silahlar insanlık tarihinde kalıcı hasarlar oluşturmuştur (Büyük Larousse'den akt. Doğan, 1995, s.33).

İkinci Dünya Savaşı sonrası, savaşın acılarını yaşayan Avrupa toplumu, neredeyse tüm siyasal, dinsel ve etik değerlerini yitirerek yaşamı anlamsız, acı veren, saçma bir eylem olarak deneyimlemiştir. Çünkü bu savaş, insanlığın tarih boyunca yaşadığı en korkunç savaş olmuş ve olumsuz etkileri günümüze kadar gelmiştir. İnsanlar savaş sonrasında bir yandan yaralarını sarmaya çalışırken bir yandan da çalışmak zorunda kalmışlardır. Bir yönüyle savaş aslında bitmemiş yalnızca boyut değiştirmiştir. Savaşın derin izleri, iletişimsizleşmiş, duygusuzlaşmış ve birbirine yabancılaşmış bir toplum yapısı ortaya çıkarmıştır.

Bu bağlamda, İkinci Dünya Savaşı'ndan sonra ortaya çıkan absürd tiyatro; herhangi bir felsefi veya ideolojik görüşün yaşamı açıklamakta yetersiz kaldığı durumlarda, insanların bunalım ve çaresizliğini yansıtma amacını taşıyan, çoğunlukla yabancılaşan insanları konu edinen tiyatro anlayışı olarak betimlenebilir. Absürd tiyatro, diğer tiyatro ve sanat akımları gibi (fütürizm, sürrealizm, ekspreyonizm, politik tiyatro, epik tiyatro), toplumsal gerçeklikleri kendi estetik ilkeleri çerçevesinde, özgün bir biçimde yansıtması bakımından üzerinde durulması gereken bir tiyatro anlayışıdır.

\section{Absürd Tiyatro}

Absürd (saçma, abes; gülünç, manasız, uyumsuz); aklı, mantı̆̆ zorlayan, selim akla uymayan düşünceler, çağrışımlar demektir. Bir toplum tarafından benimsenmiş ortak değerlere, kurallara uymayan; bireyin ya da toplumun ezelden beri alışık olduğu davranışlara ters düşen her davranış saçmadır (Karataş, 2004, s. 17).

Yalnızlığı yaşayan insanın, bulunduğu çevreye ve kendine yabancılaşmaya başladığı söylenebilir. Savaşın insanları bu denli yabancılaştırdığı bir dönemde yaşayan yazarlar, yaşadıkları toplumlardaki yozlaşmayı kaleme almış ve oyunlarında bu biçimi kullanmıştır.

Absürd tiyatronun amacı, dünyanın uyumsuz olduğunu, toplumda insanca bir düzen kurulamadığını, bireye usunun değil ilkel güdülerinin egemen olduğunu göstermek, böylece insanın kendini yapıntı düzenlemelerle avutmaktan vazgeçip saçmanın bilincine ermesini sağlamaktır (Şener, 1998, s.353). 
İkinci Dünya Savaşı sonrasında ortaya çıkan ve yaşamın akla aykırılığını, bilinen tüm sanatsal uyumları bozarak sahneye getiren tiyatro akımına "Absürd Tiyatro" (uyumsuzluk tiyatrosu) denir. Şener uyumsuzluk tiyatrosu, gerçeği mantıklı, değişmez bir düzen ya da tarihsel evrimi içindeki diyalektik ilişkiler örgüsü olarak değil, anlaşılmayan ve açıklanmayan bir karmaşa olarak görür. Bu uyumsuzluğun ancak geleneksel uyumların düzenini bozarak sahneye getirilebileceğini kabul eder. Oyunun yapısında, konuşma örgüsünde, görüntüde yeni ve us dış1 düzenlemeler yapar (Şener, 1998, s.351).

"Uyumsuz tiyatro yazarlarının ortak yanı, çağımıza özgü olan bu sorunları, tiyatro olanaklarından sonuna değin yararlanarak sahneye koymuş olmalarıdır. Bu tutum alışılagelmiş tiyatro anlayışına ters düşmüştür. Geleneksel tiyatroda, tıpkı roman ve öykü türlerinde olduğu gibi dil aracılığıyla mantık kurallarına uygun bir biçimde düzenlenmiş, başı, düğüm noktası ve sonu olan bir olay örgüsü vardır. Sahnede bu olaylar sanki gerçekmiş gibi canlandırılmaya çalışılmıştır. Oyuncular yazarın olaylarda vermek istediği karakteri sahnede canlandırırken, kendi kişiliklerini silip, rolleriyle öylesine özdeşleşmiştir ki izleyici tiyatroda olduğunu unutmuş, oyunun ve dilin büyüsü altında olayların akışına kaptırmış, yansıtılan gerçeğin içine yitip, kendini, kendi gerçeğini unutmuştur" (İpşiroğlu, 1996, s.17). Dönemin toplumsal şartları dolayısıyla ortaya çıkan bu akım, geleneksel tiyatrodaki aktarımların yetersizliğine vurgu yapmıştır. Bireyin toplumsal varlığını ortaya koyan akım, biçimsel anlamda da geleneksel tiyatroya karşı bir varoluş sergilemiştir. Çaresizlik ve bunalım içindeki insanı kendine özgü bir anlatımla betimlemiştir. Bu betimleme ile absürd tiyatro yazarları, bilinçli olarak katharsis (duygu boşalımı) yaşatmayı değil, uyumsuzluğu uyumsuz bir biçimde anlatmayı amaç edinmişlerdir.

Martin Esslin (1999, s.312), absürd tiyatroyu "günümüzün gerçek sanatçılarının, kayıtsızlık ve bilinçsizliğin ölü duvarlarını yıkma ve insana, durumunun asıl gerçeğiyle karşılaştı̆̆ında bunu fark etmesi için yeni bir bakış açısı kazandırma çabaları" olarak tanımlamıştır.

Tiyatro topluluklarında, tiyatro türlerini ayrıştırmak ve metinleri 'türe' göre incelemek için dramaturgi basamaklarından çözümleme gibi çalışmalar yapılmaktadır. 2001 yılı Ocak ayında İAPT (İstanbul Alternatif Tiyatrolar Platformu), bünyesinde yapılan "Tiyatroda Dramaturji” konulu seminerden yola çıkarak, Boğaziçi Üniversite Oyuncuları (BÜO) tarafından hazırlanan raporda "yapılmak istenen dramaturjinin sahneye yansıtılamaması" sorunu (BÜO Yıllıkları, 2002) dramaturji çalışmalarına ilişkin yeni arayışları beraberinde getirmiştir. Yapılan bu çalışmaların önemli oranını oluşturan 'oyununun türü' basamağı çözümlenmesi zor ve tiyatro topluluklarınca farklı yöntemlere ihtiyaç duyan bir çalışma konusudur. Tiyatro topluluklarında çalışma yürüten bireyler tiyatro türlerini kavramada yeni bir yöntem kullanmaya ihtiyaç duymaktadır. Ergün (2007, s.104)'e göre, "Yaşadıkları dönemin tiyatro anlayışına karşı gelen, yeni arayışlar içinde olan tiyatro sanatçılarının bir araya gelerek oluşturdukları küçük gruplarla gerçekleştirdikleri disiplinli ve deneysel çalışmaları ile tiyatro oyuncuları için yeni yöntemler oluşmaya başlamıştır." Tiyatro oyuncuları için "yaratıcı drama" bu yöntemler arasında söylenebilir.

Yaratıcı drama; bir grubu oluşturan üyelerin yaşam deneyimlerinden yola çıkarak, bir amacın, düşüncenin, doğaçlama, rol oynama $v d$. tekniklerden yararlanarak canlandırılmasıdır. Bu canlandırma süreçleri kendiliğindenliğe (spontaniteye), şimdi ve burada ilkesine, -mış gibi yapmaya dayalıdır ve yaratıcı drama, oyunun genel özelliklerinden doğrudan yararlanır (Adıgüzel, 2013, s.45). Süreçlerin yaşantıya dayalı olması katılımcılarda doğallığı sağlamakta ve ulaşılmak istenen 
amaca giderken katılımcılar, rol oynama ve doğaçlama tekniklerini uygularken daha yaratıcı düşünceler ortaya koymaktadır. Bu özellikler tiyatro oyuncuları için de söz konusudur.

Yaratıcı drama, bir yöntem olarak, sahip olduğu teknikleri işe koşarak; İngilizce öğretimi (Özbahar, 2007), masal yazma (Sevim, 2006), bilim adamlarının yaşam öyküsü (Özdemir, 2009), matematik öğretimi (Zaim, 2005), çocuk hakları eğitimi (Keleşoğlu, 2012) gibi pek çok konuyu öğretmede kullanılır. Bu yöntemde işlenecek bir konunun dramatik bir çatışma içerisinde canlandırmalarla bizzat yaşatılarak öğretilmesi söz konusudur (Adıgüzel, 2013, s.104). Anlaşılması biraz karmaşık olan Absürd Tiyatro'nun, tiyatro topluluğu öğrencileri için anlaşılabilir ve uygulanabilir olması amacıyla yaratıcı drama yöntem olarak kullanılmıştır.

Bu konuda yapılan çalışmalar incelendiğinde (Sönmez, 2011; Tüzün, 2011) yaratıcı drama yöntemiyle yapılan uygulamaların olumlu sonuçlar gösterdiği söylenebilir. Sönmez (2011)'in, Yaratıcı Drama Yöntemiyle Bir Oyun Metninin Brecht Dramaturgisine Göre Incelenmesi adlı çalışmasına göre; yaratıcı drama ile yapılan çalışmalarda, yaşantılardan yola çıkarak sürece aktarılan dramatik durumların eserlerin temel meselesinin kavranmasında bilindik dramaturji yöntemlerinden daha etkili sonuçlar oluşturduğu gözlenmiştir. Bilindik dramaturji çalışmaları oyuncu veya oyuncu adaylarının kişisel gelişimlerini, sosyal farkındalıklarını geliştirmeyi amaçlamazken yaratıcı drama ile yapılan dramaturji çalışmalarında katılımcıların bu alanda olumlu yönde gelişimi sürecin doğal sonucu olarak görülmektedir.

Tüzün'ün (2011), Berthold Brecht'in Oyunlarındaki “Gestus” Kavraminın Yaratıcı Drama Yöntemi ile Işslenmesi konulu bitirme projesinin sonuçlarına göre, tiyatral kavramların çalışılmasında yaratıcı dramanın tüm grup üzerinde olumlu etki gösterdiği gözlemlenmiştir.

Tiyatro topluluklarında; eğitim çalışmalarının daha iyi nasıl organize edilebileceği, deneysel ve araştırmacı bir tiyatro pratiğinin nasıl korunacağı ve sanatsal-estetik seviyenin nasıl yükseltileceği problemleri, ilgilenilmesi gereken sorunlar arasında görülmektedir (Orak ve Sezgin, 1998). Yaratıc1 dramanın bir sanat eğitimi alanı olma özelliğini de düşünüldüğünde (Adıgüzel, 2013, s.106), eğitim ve dramaturgi çalışmalarının daha nitelikli yapılabilmesi için, yaratıcı dramanın sunduğu tekniklerle, amatör tiyatronun iskeletini oluşturan bu çalışmaların daha verimli ve etkili olacağı söyleyebilir. Yaratııı drama çalışmalarının olanaklarıyla (katılımcıların aktif olması, yaşantılara dayalı canlandırmalar yapılması, oyunsu süreçler vb.) katılımcıları merkeze alan, deneyselliğe ve araştırmacılığa yönlendiren çalışmalar yapılabilmektedir.

Tüm bilgilere dayalı olarak amatör tiyatro topluluklarının, yaratıcı drama yöntemiyle bir tiyatro türünü çalışmalarının etkili, eleştirel ve yorumlayıcı olacağı, absürd tiyatronun eleştirel yanı ile yaratıcı dramanın sorgulatan yanının örtüşeceği ve oyuncu ile oyun açısından olumlu sonuçlar doğuracağ1 düşünülmektedir.

\section{Araştırmanın Amacı}

Absürd tiyatronun öğretiminde yaratıcı dramanın bir yöntem olarak kullanılmasının üniversite tiyatro topluluğu öğrencilerinin içerik bilgileri ile oyunculuk ve oyun yorumlama becerilerinin gelişimini araştırmak bu çalışmanın amacını oluşturmaktadır. Araştırma kapsamında, "Absürd tiyatronun ögretiminde yaratıcı dramanın bir yöntem olarak kullanılmasının üniversite tiyatro topluluğu ögrencileri üzerine etkisi nedir?” problem durumuna ilişkin aşağıdaki sorulara yanıt aranmıştır: 
- Absürd tiyatronun öğretiminde yaratıcı dramanın bir yöntem olarak kullanıldığı grubun alan/içerik bilgisi ön-test puanları ile son-test puanları arasında anlamlı bir farklılık var midır?

- Absürd tiyatronun öğretiminde yaratıcı dramanın bir yöntem olarak kullanılmasının, tiyatro topluluğu öğrencilerinin oyunculuk becerilerinin gelişimine etkisine ilişkin öğrenci görüşleri neledir?

- Absürd tiyatronun öğretiminde yaratıcı dramanın bir yöntem olarak kullanılmasının tiyatro topluluğu öğrencilerinin oyun yorumlama becerilerinin gelişimine etkisine ilişkin öğrenci görüşleri nelerdir?

- Tiyatro topluluğu öğrencilerinin absürd tiyatronun öğretiminde yaratıcı dramanın bir yöntem olarak kullanılması sürecine ilişkin görüşleri nelerdir?

\section{Yöntem}

$\mathrm{Bu}$ çalışmada nicel ve nitel araştırma yöntemlerinin bir arada yer aldığı karma yöntem kullanılmıştır. Karma yöntem araştırması, nitel ve nicel yöntemlerle veri toplama, analiz etme ve bütünleştirmeye olanak veren araştırma olarak tanımlanabilir (Cresswell ve Plano Clark'dan akt. Yıldırım \& Şimşek, 2013, s.351). Karma yöntem araştırması, araştırma problemini kapsamlı ve çok boyutlu incelemek amacıyla gerçekleştirilir (Yıldırım \& Şimşek, 2013, s.351). Çalışmanın nicel boyutunu, çalışmada deneme öncesi modellerden tek grup öntest - sontest modelinin kullanılması oluşturmaktadır. Tek grup öntest-sontest modelinde gelişigüzel seçilmiş bir gruba bağımsız değişken (yaratıcı drama uygulaması) uygulanır ve hem deney öncesi hem de deney sonrası ölçümler yapılır (Karasar, 2014, s.96). Ön ve son ölçüm puanları arasında bir değişim varsa araştırmacı bu değişimin uygulamadan kaynaklandığına inanır. Bu araştırmada, tiyatro grubu öğrencilerinin var olan durumlarını belirlemek için kullanılan ön testler yaratıcı drama yönteminin kullanılmasıyla gerçekleşen öğretimden sonra da son test olarak uygulanmıştır. Öntest ve sontest uygulamaları sonucunda elde edilen bulgular karşılaştırılarak, tiyatro grubu öğrencilerinin içerik/alan bilgileri üzerine yaratıcı drama yönteminin etkisi belirlenmiştir. Çalışmanın nitel boyutunu, tiyatro grubunda bulunan öğrencilerin yaratıcı drama uygulamalarının oyunculuk ve oyun yorumlama bilgilerinin gelişimine etkisine ilişkin görüşleri oluşturmaktır.

\section{Çalışma Grubu}

Ankara Üniversitesi Eğitim Bilimleri Fakültesi Tiyatro Topluluğu'nun üyesi olan yaşları 20-24 arasında değişen 8 kadın ve 4 erkek toplam 12 öğrenciden oluşmaktadır. Tiyatro topluluğu öğrencileri, tiyatro çalışmaları kapsamında yaratıcı drama ile ilgili temel kavram ve uygulamalara ilişkin farkındalık düzeyine sahiptir. Çalışma, 17.01.2014 - 20.01.2014 tarihleri arasında, birinci gün 3 saat, ikinci gün 6 saat, üçüncü gün 6 saat, dördüncü gün 3 saat olmak üzere toplam 18 saat süren 6 oturum biçiminde gerçekleştirilmiştir.

\section{Veri Toplama Araçları}

$\mathrm{Bu}$ çalışmanın verileri, açık uçlu sorulardan oluşan, araştırmacı tarafından hazırlanmış soru kâğıdı ve katılımcılarla gerçekleştirilen yarı yapılandırılmış görüşmeler aracılığıyla elde edilmiştir. Çalışma öncesinde ve sonrasında, katılımcıların absürd tiyatroya ilişkin bilgi düzeyini belirlemek 
üzere "Absürd Tiyatro" soru kâğıdı (Ek-1) kullanılarak katılımcıların çalışma öncesi ve sonrasındaki alan bilgisi düzeyleri arasındaki fark ortaya çıkarılmıştır. "Absürd Tiyatro" soru kâğıdında, akıma ilişkin iki, gelişime ilişkin iki, akımın temsilcilerine ilişkin bir soru yer almaktadır.

Yaratıcı dramanın, katılımcıların oyunculuk becerisi ve oyunu anlamalarına etkisini belirlemek üzere katılımcılarla yarı yapılandırılmış görüşmeler gerçekleştirilmiştir (Ek- 2). Yarı yapılandırılmış görüşmede araştırmacı önceden sormayı planladığı soruları içeren görüşme protokolünü hazırlar. Buna karşın araştırmacı görüşmenin akışına bağlı olarak yan ya da alt sorularla görüşmenin akışını etkileyebilir ve kişinin yanıtlarını açmasını ve daha ayrıntılı olarak ifade etmesini sağlayabilir. Eğer kişi görüşme esnasında belli soruların yanıtlarını başka soruların içerisinde yanıtlamış ise araştırmacı bu soruları sormayabilir (Yıldırım \& Şimşek, 2013, s.148). Hazırlanan görüşme sorularıyla ilgili üç konu alan uzmanının görüşü alınmıştır. Daha sonra iki alan uzmanı ile ön görüşme yapılmış ve yapılan görüşme sonunda sorulara son şekli verilmiştir.

\section{Uygulama Süreci}

Çalışmanın uygulamasında, katılımcıların Absürd Tiyatroyu tanıması, Absürd Tiyatronun ortaya çıkış nedenlerini anlaması, Absürd Tiyatro öncülerini ve örneklerini tanımasına yönelik atölyeler yapılmıştır. Atölyelerin genel değerlendirmesi, son oturumda Jean Genet'in 'Balkon' oyunundaki absürd ögelerin belirlenmesiyle gerçekleştirilmiştir. Atölye başlıkları aşağıdaki gibidir:

Birinci Oturum: Absürd Tiyatro

İkinci Oturum: Absürd Tiyatronun Ortaya Çıkışı ve Nedenleri- I

Üçüncü Oturum: Absürd Tiyatronun Ortaya Çıkışı ve Nedenleri- II

Dördüncü Oturum: Başlıca Absürd Tiyatro Yazarları ve Oyunları

Beşinci Oturum: Absürd Tiyatroya Bir Örnek: Jean Genet "Balkon” Oyunu

Altıncı Oturum: Jean Genet “Balkon” Oyunundaki Absürd Öğeler

\section{Verilerin Analizi}

Verilerin analizinde, "Absürd Tiyatro" soru kâğıtlarında bulunan alan bilgisini içeren soruların değerlendirilmesi amacıyla geliştirilen üçlü rubrik (dereceli puanlama anahtarı, Ek-3) kullanılmıştır. Çalışma kapsamında rubrik, öğrencilerin alan bilgisine yönelik soru kâğıtlarından aldıkları puanların belirlenmesi amacıyla hazırlanmıştır. Bu kategorilere ait performans düzeyleri ve kriterler araştırmacı tarafından geliştirilmiş ve iki alan uzmanından görüş alınarak son şekline getirilmiştir. Geliştirilen rubrik ile puanlandırılan öntest ve sontest verileri arasında istatiksel olarak anlamlı bir fark olup olmadığını anlamak amacıyla Wilcoxon işaretli sıralar testi ile analiz edilmişstir.

Araştırma kapsamında gerçekleştirilen yarı yapılandırılmış görüşmelerden elde edilen verilerin analizinde betimsel analiz kullanılmıştır. Betimsel analize göre, elde edilen veriler, çoğunlukla alan yazından belirlenen temalara göre özetlenir ve yorumlanır. Doğrudan alıntılarla katılımcıların görüşlerine yer verilir (Yıldırım \& Şimşek, 2013, s.256). 


\section{Bulgular}

Veri toplama araçları aracılığıyla ulaşılan bulgular; yaratıcı dramanın içerik bilgisinin gelişimine etkisine ilişkin bulgular, oyunculuk becerisinin gelişimine etkisine ilişkin bulgular, oyun yorumlama becerisinin gelişimine etkisine ilişkin bulgular ve sürece ilişkin görüşlere yönelik bulgular şeklinde başlıklandırılmıştır.

\section{Tiyatro Topluluğu Öğrencilerinin Alan/İçerik Bilgisinin Gelişsimine İlişkin Bulgular}

Araştırmanın birinci alt problemi, “Absürd tiyatronun öğretiminde yaratıcı drama yönteminin kullanıldığı grubun alan/içerik ön-test puanları ile son-test puanları arasında anlamlı bir farklılık var mıdır?"şeklinde kurgulanmıştır. Bu alt problemin çözümü için ilk olarak öğrencilerin bilgi düzeylerindeki gelişimi görmek amacıyla konu ile ilgili olarak hazırlanan açık uçlu soru kâğıd, uygulama öncesinde ve sonrasında öğrencilere uygulanmıştır. Öğrencilerin verdikleri yanıtlar, geliştirilen rubrik aracılığıyla puanlanmıştır. Öntest ve sontest arasında istatistiksel olarak anlamlı bir fark olup olmadığını anlamak amacıyla Wilcoxon işaretli sıralar testi sonuçları çizelge 1'de sunulmuştur.

Çizelge 1. Deney Öncesi ve Sonrası İçerik Bilgisi Soru Kă̆ıdı Puanlarının Wilcoxon İşaretli Siralar Testi Sonuçları

\begin{tabular}{lccccc}
\hline Sontest-Öntest & $\mathbf{n}$ & Sıra Ortalaması & Sıra Toplamı & $\mathbf{Z}$ & $\mathbf{P}$ \\
\hline Negatif Sıra & 0 & .00 & .00 & $2,94^{*}$ & .003 \\
Pozitif Sıra & 11 & 6.00 & 66.00 & & \\
Eşit & 0 & - & - & & \\
\hline
\end{tabular}

* Negatif stralar temeline dayalı

İçerik bilgisi soru kâğıdında toplam beş soru bulunmaktadır. Her soru 3 puan olacak biçimde toplam 15 puan üzerinden değerlendirme yapılmıştır. Analiz sonuçları, araştırmaya katılan öğretmen adaylarının içerik bilgisi soru kâğıdından aldıkları deney öncesi ve sonrası puanlar arasında anlamlı bir fark olduğunu göstermektedir $(\mathrm{z}=2,94, \mathrm{p}<.01)$. Fark puanlarının sıra ortalaması ve toplamları dikkate alındığında, gözlenen bu farkın pozitif sıralar, yani son test puanı lehine olduğu görülmektedir. $\mathrm{Bu}$ sonuçlara göre, yaratıcı drama uygulamalarının tiyatro topluluğu öğrencilerinin absürd tiyatroya ilişkin alan bilgisini geliştirme lehine önemli bir etkisinin olduğu söylenebilir.

\section{Yaratıcı Dramanın Oyunculuk Becerisine Etkisine Yönelik Görüşlere İlişkin Bulgular}

Absürd tiyatronun işlenmesinde yaratıcı dramanın bir yöntem olarak kullanılmasının tiyatro topluluğu öğrencileri üzerindeki etkisini belirlemeyi amaçlayan bu çalışma kapsamında gerçekleştirilen yaratıcı drama atölyelerinin ardından katılımcılarla yapılan yarı yapılandırılmış görüşme sonucunda, yaratıcı dramanın katılımcıların oyunculuk becerilerini çeşitli açılardan etkilediği belirlenmiştir. Katılımcılara göre yaratıcı drama, onların oyunculuk becerilerini özellikle role girme, karakteri anlama ve hissetme, dönem özelliklerini kavrama açısından olumlu yönde etkilemiştir. Katılımcıların bu duruma ilişkin görüşleri şu şekilde gösterilebilir: 
K1:Oyunculuk açısından yaratıcı drama, düşündü̈̆̈̈n bir rolü anlatabilmek için role girmede o dönemi ve rolü hissetme de yardımcı oldu.

K2: Yaptığımı varoluşçu ve absürd tiyatro türlerindeki drama etkinlikleri bana oyunun geneline bakarak oyunu sahneleme sürecinde oyunculuğun da oyunu anlamada ve seyirciye anlatmada önemli etkileri olduğunu gösterdi.

K5: Yaratıcı drama çalışması oyunculuk becerilerim üzerinde olumlu bir etki yarattı. Duygulara girebilmek ve canlandırdı̆̆ım karakteri anlamak için neler yapabileceğim konusunda yol gösterdi. Karakterin hayatının, yaşadığı ortamın, ailesinin, yaptığı işin, karakterin ait olduğu zaman diliminde toplumda mevcut olan olayların karakteri nasıl etkilediğini gördüm.

K8: Yaratıcı Drama uygulamasında yaptığımız doğaçlama ve oyun çalışmalarının, etkinlikler ve canlandırmaların sonucunda farkl rollere bürünmeye çalışmak ve üstlendiğimiz rolü canlandırırken nelere dikkat etmemiz gerektiğini öğrenmenin oyunculuk becerilerimiz üzerinde etkili olduğunu düşünüyorum.

K9:Yaptı̆̆ımız yaratıcı drama çalışmasının oyunculuk becerilerimi olumlu yönde etkilediğini düşünüyorum. Bunun nedeni daha önce tecrübe edinmediğim bir oyunculuk deneyimiydi. Bir duyguyu önce yaşamaya ve hissetmeye çalışmak, hemen ardından onu yansıtmak daha önce yapmadı̆̆ım bir uygulamaydı ve çalışma içerisinde bahsedilen kahramanların nasıl davranması, düşünmesi gerektiğini biliyorsunuz; ancak bunu izleyenlere yansitabilecek misiniz? Yoksa bu sadece sizin hayal dünyanız içerisinde mi kalacak? Böyle bir etkinliği tecrübe edinmiş olmak, oyunculuk becerilerimi geliştirmemi să̆ladl.

Yaratıcı drama uygulamalarının katılımcıların oyunculuk becerileri üzerine bir başka etkisi incelendiğinde yapılan doğaçlama çalışmalarının oyunculuk teknikleri (replik atma), sahne teknikleri (sahne kullanımı), beden kullanımı ve bireysel performansı arttırması açısından katılımcıların oyunculuk becerilerini olumlu yönde etkilediği düşünülmektedir.

K1: Balkon oyununun sahnelerini gruplara bölerek doğaçlama sahneye koyduğumuz bir etkinlik sırasında oyun çalışmalarında fark etmediğim oyunculuk ve sahne teknikleri geliştirebildiğimizi gördüm. Yaratıcı drama adı üstünde kişiyi yaratmaya, düşünmeye sevk eden ve oyunculuk teknikleri açısından geliştiren bir araç olduğunu fark ettim.

K2: Atölye çalışmasının oyunculuk anlamında diğer bir faydası ben ve diğer ekip arkadaşlarımın sahnedeki performansımızı iki hatta üç katına çıkarmamızın mümkün olduğunu görmemiz olmuştur.

K4: Oyunculuk için illa replik atmanın gerekli olmadiğını sadece hareketlerle de karşındakine istediğin mesajı verebildiğini gördüm, öğrendim. Bu uygulama sayesinde oyuncu olarak nerede nasıl durmam gerektiğini, replik atarken nelere dikkat etmem gerektiğini öğrendim. Karşımdaki insan zor durumda kalınca onu nasıl kurtarmam gerektiğini, oyunu nasıl toparlamam gerektiğini öğrendim.

K5: Bedenimle iletişim kurma ve bedenime hakim olma konusunda yararlı bir çalışmaydl. Aynı zamanda sahnedeki dekorla, diğer oyuncularla uyumlu olma konusunda faydallydl. Hem kendi bedenim, aklım ve duygularım arasındaki uyumu hem de diğer oyuncular ve sahne ortamı ile olan uyumu nasıl yakalayacă̆ım konusunda yol göstericiydi.

K12: Sesi ve sahneyi kullanma, kendini gösterme, doğaçlama becerileri anlamında başlangıç düzeyinde iyi yöntem olduğunu düşünüyorum. 
Yaratıcı drama uygulamalarının sahne ve oyunculuk becerilerinin yanı sıra katılımcıların kendilerini keşfetmeleri ve daha iyi tanımalarında da etkisinin olduğu şu şekilde ifade edilmektedir:

K1: Farklı rol oynamalarla kendimi oyunculuk açısından keşfettim.

K7: Insanı daha sosyal, daha insancıl ve daha kendini bilen biri yaptığını düşünüyorum çünkü kişi kendinin bilincinde oluyor neler yapabilirmiş, neleri yapmak için kendini nasıl geliştirebilirmiş yaratıcı dramada görüyor.

Katılımcılara göre, gerçekleştirilen uygulamalar ve yapılan doğaçlama çalışmaları kişilerin kendilerini tanımalarının yanı sıra kendilerine bir şeyleri yapabildiklerini göstererek katılımcıların özgüvenlerinin artmasını sağlamıştır. Bu durum katılımcılar tarafından şu şekilde belirtilmektedir:

K2: Aynı zamanda doğaçlama çalışmaları, yapamayacă̆ımı düşündüğüm şeyleri yapabildiğimi göstermesinin yanında özgüvenimin gelişmesinde büyük etkisi oldu.

K12: Yaratıcl dramanın oyunculuk üzerinde etkili olduğunu düşünüyorum. Kişilerin yaşantısından yola çıkması küçük adımlarla özgüvenini pekiştirmekte, kendini ifade etmesi için firsat sağlamaktadır.

Tiyatro topluluğu öğrencileri olan katılımcılar için topluluk önünde heyecanlanmadan rahat hareket etmek oldukça önem taşımaktadır ve yapılan uygulamaların kendilerini topluluk önünde rahat hissetmelerini sağlayarak heyecanlarını azalttığı şu şekilde belirtilmektedir:

K11: Yeni bireyler için oyunculuk üzerindeki heyecanı atarak kendilerini daha rahat hissetmelerini săglıyor. Yaratıcı drama ile kendimi hem uygulamanın içerisinde bir parçası olduğunu anliyorum ve rahat davranabiliyorum hem de bu rahatlkla heyecanimı yenebiliyorum.

K11: Yaratıc drama sayesinde oyunculukta kendimi oyun oynarken herkesin bana baklyor gibi hissetmesinden ziyade herkesle bir bütün içerisinde olduğum için kendimi kasmaya değil oyunu daha rahat oynanmamı să̆lıyor.

18 saatlik atölye çalışmaları sonucunda yaratıcı drama çalışmalarının katılımcıları oyunculuk becerilerini; role girme, karakteri anlama ve hissetme, dönemi anlamayı kolaylaştırma, sahne ve oyunculuk teknikleri, beden ve ses kullanımı, sahne kullanımını geliştirme ve heyecanı azaltma gibi noktalarda olumlu yönde etkilediği belirlenmiştir.

\section{Yaratıcı Dramanın Oyun Yorumlama Üzerine Etkisine Yönelik Görüşlere İlişkin Bulgular}

Çalışma kapsamında, yaratıcı drama çalışmalarının tiyatro topluluğu öğrencilerinin oyun yorumlama sürecine etkisi incelenmiştir. Bu doğrultuda, yaratıcı dramanın katılımcıların oyunu anlamasını kolaylaştırdığı belirlenmiştir. Katılımcılara göre yaratıcı drama, tiyatro oyununu yorumlama sürecini özellikle oyunu anlama, oyunu sahneleme ve oyuna / karaktere hâkimiyeti arttırma açısından onları olumlu yönde etkilemiştir. Katılımcıların bu duruma ilişkin görüşleri şu şekilde gösterilebilir:

K1: Balkon oyununu anlamak yaratıcı drama atölyesiyle daha kolay oldu. Çünkü absürd oyun nedir, dönemin özellikleri, ortaya çıkışı, karakterlerin analizleri gibi konular okuma gerektiren ve çoğu insanı zorlayan konulardı ama drama atölyesiyle bu konular hem ĕ̆lenceli hem akılda kalıcı hale geldi. 
K2: Yaptı̆̆ımız drama çalışması; özellikle diğer türlerden farklı olan absürd türündeki bir oyunu anlamamızda ve sahne üzerinde uygulama aşamasına geçmemizde çok önemli etkileri oldu. Yaptı̆̆ımı etkinlikler dönemin siyasi, sosyal ve kültürel özelliklerini kavramamızı ve bu özellikleri oyunla bağdaştırmamızı ve daha iyi anlamamızı să̆ladı. Yaratıcı drama atölye çalışmasını çalışmanın öncesi ve sonrası olarak ayırırsak; öncesinde oyunla ilgili kafamda çözümleyemediğim birden çok soru işareti mevcutken sonrasında oyunla ilintili neredeyse tüm kafa karışılklılarım yaptı̆̆ımız çalışmalar sayesinde ortadan kayboldu.

K3: Analiz ve sentez becerileri üzerinde de olumlu etkisi olan yaratıcı dramanın sadece bir oturumundan sonra yapılan bir oyun yorumu bile defalarca okunan bir oyun yorumundan çok daha fazla şey katacaktır ve okurlar için de çok daha fazla tercih edilebilir olacaktır.

K4: Bu uygulamada tiyatro ile ilgili bilmediğim terimleri öğrendim. Oyunları okurken nerede nelere dikkat etmek gerektiğini, bir cümlenin birden çok anlam ifade edebildiğini fark ettim. Yaptı̆̆ımı drama örneklerinden yola çıkarak oyunları okurken nasıl bir yol izlemem gerektiğini fark ettim.

K5:Yaratıcı drama çalışması oyun yorumlama sürecini kuramsallıktan çıkarıp içselleştirmeye yönelik olarak büyük fayda sağladl. "Satırların ötesini” görebilme adına algılarımızı açmamız ve oyuna dışarıdan değil içeriden bir göz olarak bakabilmemiz gerekiyordu ve bunu nasıl yapacağımız konusunda bize yöntem ögreten şey yaratıcı dramaydı.

K7:Daha önce normal bir tiyatro türünün bile nasıl oynanacağına dair bir fikrim yokken absürd tiyatroyu nasıl anlayabilirdim bilmiyorum tabi siz olmasaydınız. Illk duyduğumda herhangi bir türdür işte, diye düşündüm fakat oyunu kavramaya çalışırken bir türlü fikir oturtamıyorduk bu da bana absürd türün herhangi bir tür olmadiğını gösterdi tam olmayacak sanırım akışına bıraksam daha iyi, derken yaratıcı drama çalışmalarımıza katıldınız ve çeşitli drama etkinlikleriyle bize sadece absürd türünün özelliklerini değil nasıl oluştuğunu, içinde neleri barındırdı̆̆ını, kısacası bu türün sırlarını kavrattınız ve belli ki bunu bize kavratmak için bizden çok daha fazla çalıştınız.

K8: Yaratıcı Drama etkinlikleri sırasında oyunu okurken nelere dikkat etmemiz gerektiğini ve hangi etmenleri göz önünde bulundurmamız gerektiğini ögrendik (oyunun türü, yazarı ve yazarın etkilendiği dönem hakkındaki bilgiler gibi).

K9: "Yaşanmış olayları, o olayın tarihine göre değerlendirin." Tarihçiler için temel olmuş bu söz, aslında izlediğimiz ya da okuduğumuz oyunlar için de geçerli. Ancak bir oyunu seyrederken, o oyunu sadece karakterlerin, dekorun ve duyguların bize yansittı̆ $ı$ kadartyla algılayabiliyoruz. Aslında olması gereken, yazarın bu oyunu yazdĭ̆ dönemi ve dönemin etkilerini de bu algiya dahil edebilmek. Yaratıcı dramada yaptığımız bu çalışmalar, beni oyunun içine girebilme, dönemi ve o dönemin yarattı̆ğ duyguları algıma dahil edebilme konusunda geliştirdi. O yüzden kesinlikle etkili olduğınu düşünüyorum.

K10: Oyun yorumlayabilmek için üzerine birikimli bir bilgi ve düşünme yetisi gerekli. Bunun için yaratıcı drama yeterince toparlayıcı bir etken.'

K11: Oyun yorumlama da etkisi olduğunu düşünüyorum. Çünkü yaratıcı drama sayesinde oyunun temellerine inerek hangi durumlar yaşandı̆̆ını, olayın o dönemde nasıl olduğunu görebiliyoruz. 
K12: Oyunu yorumlamada şöyle etkili: oyunun alt metnini kavrayabilmek için ufak detayları görebilmek ve oyunun kilit noktalarını özümseyebilmek önemlidir. Bu açıdan dramanın faydalı olduğunu düşünüyorum.

Katılımcılardan birine (K5) göre, yapılan çalışmanın katılımcılara farklı bakış açıları kazandırması, oyunu sahneleme sürecini olumlu yönde etkilemiştir. Yaratıcı dramanın oyun yorumu ve sahneleme süreci arasında bir uyum oluşturduğu gözlenmiştir.

K5: Gözde canlandırma, ayrıntıları görebilme, ilişki kurma ve farklı açılardan bakabilme konusunda ufuk açıcı bir çalışmaydl. Okumak, anlamak, yorumlamak şeklinde giden süreçte işin içine nasıl kendi yaratıcılı̆̆ımızı, kendi duygularımızı oyunla uyum içinde katabileceğimiz konusunda çok şey ögrendim.

Yaratıcı drama çalışmalarındaki türe ilişkin doğaçlamaların katılımcıların oyunu yorumlamalarını olumlu yönde etkilediği ve bir oyundaki karakterleri çözümlemenin oyunu yorumlamayı kolaylaştırdığı belirlenmiştir. Katılımcılara göre -mış gibi yapmak, kendini başkasının yerine koymak onların oyuna hakimiyetini arttırıcı bir etki yaratmıştır. Belli kalıplara bağlı kalmadan hareket eden katılımcılar, yaratıcı drama çalışmaları ile zaman ve mekan çalışmalarının oyunu sahneye taşırken yorumlamayı kolaylaştırdı ğını belirtmişlerdir.

K2: Yaptığımız doğaçlama çalışmalarıyla o dönemi birebir yaşıyormuşuz gibi hareket etmemiz, oyundaki karakterler üzerine daha çok düşündürerek karakterlerle empati kurmamızı sağladı ve oyuna hakim olduğumuzu hissetmemizde en büyük etkenlerden biri oldu.

K6: Yaratıcı drama oyuncuyu bir kalıba sokmaktan çok kendi kalıbını oluşturmasına yardım eder. Oyuncu kalıbını oluşturduktan sonra oyunu yorumlaması, bakış açısı, içselleştirmesi ve bunu sahneye yansıtması da hiç yaratıcı drama çalışması yapmamış birine göre farklıdır.

K8: Yaratıcı drama ile yapılan doğaçlama çalışmalarıyla kendimizden neler katabileceğimizi görmek oyunu yorumlamamı konusunda yardımcı oldu. Bu yüzden yaratıcı dramanın oyun yorumlamada etkili olduğunu düşünüyorum.

K11: Kendinizi oyunun karakterine göre yönlendirmenizde yardımcı oluyor. Yaratıcı drama sayesinde oyunun zaman ve mekân unsurlarından yola çıkarak oyunda söz edilen zamanın oyuna olan etkisini anlamanızda yardımcı oluyor.

Atölye çalışmaları sonucunda, yaratıcı drama çalışmalarının katılımcıların oyun yorumlamalarını; oyunu anlama, oyun sahneleme, oyuna ve karaktere hâkimiyeti arttırma gibi noktalarda olumlu yönde etkilediği belirlenmiştir.

\section{Yaratıcı Drama Çalışmaları Sürecine İlişkin Bulgular}

Yaratıcı drama yöntemi ile absürd tiyatronun işlenmesi sürecinde gerçekleştirilen yaratıcı drama atölye çalışmaları süreç açısından değerlendirildiğinde, bu sürecin katılımcılar açısından yaparak yaşayarak öğrenme ortamı oluşturduğu ve eğlendirici yönü vurgulamıştır. Katılımcılar yaparak, yaşayarak öğrendiklerini şu şekilde ifade etmişlerdir:

K1: Yaratıcı drama atölyesi sırasında yapılan etkinlikler, rol oynama gibi tekniklerle yaparak yaşayarak ögrenme yolunu açtı ve bir oyunu anlamanın ne kadar önemli gerekli olduğunun yanı sıra bunun ne kadar ĕglenerek olacağını anlamış olduk. 
K4: Yaptı̆̆ımız drama örneklerinden yola çıkarak oyunları okurken nasıl bir yol izlemem gerektiğini fark ettim.

K5: Ruh halinin, görünümünün, konuşmasının hatta beden dilinin bile pek çok yaşantıdan etkilenerek son haline geldiğini yaşayarak gördüm. Yaratıcı drama çalışmamız bunları irdelemenin ve içselleştirmenin karaktere girmede ne kadar önemli olduğunu gösterdi.

K10: Düşünmek, hissetmek, onu yaşamak yaratıcı dramanın anlamı bence. Hayat bile prova ederek yaşanıyor. Oyun oynamak da yaratıcı dramayla bu şekilde bütünleşmiş bir etken.

K12: Bir de dramada yaşantıyı deneyimleme gibi bir firsat olduğu için oyunun anlattıklarını yaşayarak içselleştirdik.

$\mathrm{Bu}$ da gösteriyor ki yaratıcı drama yöntemiyle hangi konu çalışılırsa çalışılsın yaparak ve yaşayarak öğrenme, eğlenerek öğrenme sonuçlarına ulaşılmaktadır.

\section{Sonuç ve Öneriler}

$\mathrm{Bu}$ çalışma sonucunda üniversitede tiyatro yapan bireylerin, bir tiyatro türünü yaratıcı drama yöntemiyle çalışmalarının etkili olduğu görülmektedir. Absürd Tiyatro'nun eleştirel, yaratıcı dramanın da sorgulatan yanının örtüştüğü, elde edilen bulgularda oyuncu ile oyun açısından olumlu sonuçlar ortaya çıkardığı gözlenmektedir. Anlaşılması kolay olmayan Absürd Tiyatro’ nun, yaratıcı drama yöntemiyle tiyatro topluluğu öğrencileri için daha anlaşılabilir ve uygulanabilir olduğu bu çalışma sonunda ortaya çıkmıştır. Bu nedenle Absürd Tiyatro anlayışının kavranmasında ve bu anlayış doğrultusunda yapılacak okumalarda yaratıcı dramanın kullanılabilecek etkin bir yöntem olduğu söylenebilir.

Elde edilen bulgularda yaratıcı dramanın oyunculuk becerisine, tiyatro oyunu yorumlama becerisine katkı sağladığı görülmekte, ayrıca yaratıcı dramanın yaparak yaşayarak öğrenme, eğlenerek öğrenme açısından da etkili bir yöntem olduğu katılımcılar tarafından vurgulanmaktadır.

Tiyatro topluluklarına yaratıcı drama eğitimlerinin verilmesi, yaratıcı drama yöntemiyle dramaturgi ve çalışılacak oyunun türüne göre çalışmalar yapılmasının topluluk üyelerine oyunu anlamlandırma konusunda katkı sağlayacağı düşünülmektedir. Oyun hazırlıkları öncesi metne geçmeden önce doğaçlamalar yapılması, metindeki bazı repliklerden yola çıkarak yaratıcı drama çalışmalarının yapılması oyunun rejisini zenginleştirebilir ve daha anlamlandırılmış bir oyun sergilenmesini sağlayabilir. Bu nedenle tiyatro çalışmaları yürütecek bütün topluluklara yaratıcı dramanın tanıtılması ve yaratıcı drama eğitimleri verilmesi önerilmektedir. 


\section{Kaynakça}

Adıgüzel, Ö. (2013). Eğitimde yaratıcı drama (4. bs.). Ankara: PegemA Yayıncılık.

Aristoteles. (2010). Poetika. (İ. Tunalı, Çev.). İstanbul: Remzi Kitapevi.

Armaoğlu, F. (2007). 20. Yüzyll siyasi tarihi. İstanbul: Alkım Yayınevi.

Aydın D.- Özdinç Ö. (2002). Boğaziçi Üniversitesi Oyuncuları Yıllık 2001-2002, sayı: 3, İstanbul.

Aytaş, G.- Yalçın, A. (2002). Tiyatro ve canlandırma-önsöz. Ankara: Akçă̆ Yayınları.

Beckett, S. (1993). Tüm kısa oyunları (U. Ün, Çev.). İstanbul: Mitos Boyut Yayınları.

Brockett, Oscar G. (2000). Tiyatro tarihi. Ankara: Dost Kitapevi.

Büyüköztürk, Ş. ve Çakmak, Kılıç, E. ve Akgün, Ö. E. ve Karadeniz, Ş. ve Demirel, (2008). Bilimsel araştırma yöntemleri. Ankara: Pegem A Yayınclık.

Doğan, H.G. (1995). Tiyatro ve eğitim ilişsisinde bir örnek: Uyumsuz (Absürd) tiyatro. Yayınlanmamış Yüksek Lisans Tezi. Ankara Üniversitesi, Sosyal Bilimler Enstitisü.

Ergün, S. (2007). Oyuncu eğitimi için farklı dramaturgi yöntemleri. Yaratıcı Drama Dergisi 3-4, 104, Ankara. Esslin, M. (1999). Absürd tiyatro. Ankara: Dost Kitabevi.

Genet, J. (2006). Balkon (B. Sabuncu, Çev.). İstanbul: Ayrıntı Yayınları.

Ionesco, E. (1965). Kel şarkıcı (Ü. Tamer- G. Erkal, Çev.). İstanbul: de Yayınevi.

Ionesco, E. (2000). Toplu oyunları 4 (H. Anamur, Çev.). İstanbul: Mitos Boyut Yayınları.

İpşiroğlu, Z. (1988). Tiyatroda devrim. İstanbul: Çağdaş Yayınları.

İpşiroğlu, Z. (1996). Uyumsuz tiyatroda gerçekçilik. İstanbul: Mitos Boyut Yayınları.

Karasar, N. (2014). Bilimsel araştırma yöntemi. Ankara: Nobel Yayıncılık.

Karataş, T. (2004). Edebiyat terimler sözlüğ̈̈. Ankara Akçă̆ Yayınları.

KONGAR, E. (1976). Toplumbilim Açısından Tiyatro. Tiyatro Araştırmaları Dergisi, 7, 33-43.

Kurt, F. (2009). Mehmet Baydur'un Oyunlarının Absürd Tiyatro Özellikleri Bakımından Incelenmesi. Yüksek Lisans Tezi, Eskişehir: Osman Gazi Üniversitesi.

Nutku, Ö. (1985). Dünya tiyatro tarihi. Remzi Kitapevi.

Piscator, E. (2012). Politik tiyatro (M. Ünlü- S. Güney, Çev.). İstanbul: Agora Kitaplığı.

Sezgin, B. ve Orak, B. (1998). Üniversite Tiyatrosu Tartı̧̧aları. İstanbul: Amatör Tiyatro Çevreleri (ATÇ) yayınlanmamış kitapçık.

Sönmez, S. (2011). Yaratıcı drama yöntemiyle bir oyun metninin Brecht dramaturgisine göre incelemesi. Yayınlanmamış Bitirme Projesi, Çağdaş Drama Derneği, Ankara.

Şener, S. (2012). Dünden bugüne tiyatro düşüncesi. Ankara: Dost Kitapevi.

Tanilli, S. (2006). Uygarlk tarihi. İstanbul: Alkım Yayınevi.

Turani, A. (1971). Dünya sanat tarihi. Ankara: Türkiye İş Bankası Kültür Yayınları.

Tüzün, Z. (2013). Berthold Brecht'in oyunlarındaki "gestus” kavramının yaratıcı drama yöntemiyle işlenmesi Işslenmesi. Yayınlanmamış Bitirme Projesi, Çağdaş Drama Derneği, Ankara.

Yıldırım, A. \& Şimşek, H. (2013). Sosyal bilimlerde nitel araştırma yöntemleri. Ankara: Seçkin Yayıncılık. 


\section{Ekler}

\section{Ek-1: “Absürd Tiyatro” Başarı Testi Soruları}

1. Absürd Tiyatro'yu kendinizce tanımlayınız.

2. Absürd Tiyatronun doğuşu hakkında bildiklerinizi yazınız.

3. Varoluşçuluk sizin için ne anlam ifade ediyor?

4. Absürd Tiyatro temsilcilerinden bildiklerinizi yazınız.

5. Dramatik Kurgunun bileşenleri hakkında neler biliyorsunuz?

\section{Ek-2: Yarı Yapılandırılmış Görüşme Soruları}

1. Yaratıcı Drama uygulamasının oyunculuk becerileriniz üzerinde bir etkisi olduğunu düşünüyor musunuz? Lütfen açıklayınız.

2. Oyun yorumlamada yaratıcı dramanın etkili olduğunu düşünüyor musunuz? Lütfen açıklayınız.

\section{Ek-3: “Absürd Tiyatro” Soru Kağıdına İlişkin Rubrik}

\begin{tabular}{|c|c|c|c|c|}
\hline \multirow[t]{2}{*}{ KRİTER } & \multicolumn{4}{|c|}{ PERFORMANS DÜZEYLERİ } \\
\hline & 0 (Zayıf) & 1 (Orta) & 2 (İyi) & 3 (Çok iyi) \\
\hline $\begin{array}{l}\text { Absüd tiyatronun } \\
\text { tanımlanması }\end{array}$ & $\begin{array}{l}\text { Tanımlanmamış } \\
\text { ya da yanlış } \\
\text { tanımlanmıştır. }\end{array}$ & $\begin{array}{l}\text { Tanıma ait } \\
1-2 \text { özellik } \\
\text { yazılmıştır. }\end{array}$ & $\begin{array}{l}\text { Tanıma ait } 3 \text { özellik } \\
\text { yazılmıştır. }\end{array}$ & $\begin{array}{l}\text { Tanıma ait } 4 \text { veya } \\
\text { daha fazla özellik } \\
\text { yazılmıştır. }\end{array}$ \\
\hline $\begin{array}{l}\text { Absürd tiyatronun } \\
\text { doğuşundaetkili } \\
\text { olan kavramlar }\end{array}$ & $\begin{array}{l}\text { Absürd tiyatronun } \\
\text { doğuşuna etki } \\
\text { eden kavramlardan } \\
\text { hiçbiri yazılmamış } \\
\text { ya da yanlış } \\
\text { yazılmıştır. }\end{array}$ & $\begin{array}{l}1 \text { ya da } 2 \text { kavram } \\
\text { yazılmıştır. }\end{array}$ & $\begin{array}{l}\text { 3-5 arası kavram } \\
\text { yazılmıştır. }\end{array}$ & $\begin{array}{l}\text { Absürd tiyatronun } \\
\text { doğuşunda etkili } \\
\text { olan kavramların 6-8 } \\
\text { tanesi yazılmıştır. }\end{array}$ \\
\hline $\begin{array}{l}\text { Varoluşçuluğun } \\
\text { tanımlanması }\end{array}$ & $\begin{array}{l}\text { Tanımlanmamış } \\
\text { ya da yanlış } \\
\text { tanımlanmıştır. }\end{array}$ & $\begin{array}{l}\text { Tanıma ait } \\
\text { 1-2 özellik } \\
\text { yazılmıştır. }\end{array}$ & $\begin{array}{l}\text { Tanıma ait 3-5 } \\
\text { özellik yazılmıştır. }\end{array}$ & $\begin{array}{l}\text { Tanıma ait 6- } 8 \\
\text { özellik yazılmıştır. }\end{array}$ \\
\hline $\begin{array}{l}\text { Absürd tiyatronun } \\
\text { temsilcileri }\end{array}$ & $\begin{array}{l}\text { Tmsilcilerden } \\
\text { hiçbiri yazılmamış } \\
\text { ya da yanlış } \\
\text { yazılmıştır. }\end{array}$ & $\begin{array}{l}\text { Temsilcilerden } \\
1-3 \text { isim } \\
\text { yazılmıştır. }\end{array}$ & $\begin{array}{l}\text { Temsilcilerden 4-6 } \\
\text { isim yazılmıştır. }\end{array}$ & $\begin{array}{l}\text { Temsilcilerin 9'u da } \\
\text { yazılmıştır. }\end{array}$ \\
\hline $\begin{array}{l}\text { Dramatik } \\
\text { kurgunun } \\
\text { bileşenleri }\end{array}$ & $\begin{array}{l}\text { Dramatik kurgunun } \\
\text { bileşenlerinden hiç } \\
\text { biri yazılmamış } \\
\text { ya da yanlış } \\
\text { yazılmıştır. }\end{array}$ & $\begin{array}{l}\text { Dramatik } \\
\text { kurgunun } \\
\text { bileşenlerinden } \\
\text { 1-3 tanesi } \\
\text { yazılmıştır. }\end{array}$ & $\begin{array}{l}\text { Dramatik kurgunun } \\
\text { bileşenlerinden 4-6 } \\
\text { tanesi yazılmıştır. }\end{array}$ & $\begin{array}{l}\text { Dramatik kurgunun } \\
\text { bileşenlerinden } 7-10 \\
\text { tanesi yazılmıştır. }\end{array}$ \\
\hline
\end{tabular}




\section{Ek 4: Örnek Ders Planı (Birinci Oturum)}

Konu: Absürd Tiyatro’ya giriş

Grup: Ankara Üniversitesi Eğitim Bilimleri Fakültesi Tiyatro Topluluğu (ETİK Oyuncular1), 8 Kadın- 4 Erkek

Süre: 180 dakika

Mekân: Ankara Üniversitesi Eğitim Bilimleri Fakültesi Drama Salonu

Yöntem /Teknikler: Yaratıcı drama(Doğaçlama, Rol oynama, Donuk imge)

Araç- Gereçler: Absürd tiyatronun tanımında geçen kavramların yazılı olduğu kâğıtlar, meslek isimlerinin yazılı olduğu kağıtlar, "Balkon" oyunundan alınmış repliklerin yazılı olduğu kağıtlar, Grup sayısından 4 adet fazla A4 kağıd1, Eugene Ionesco' nun "Kel Şarkıcı" ve "Gergedanlar” oyunundan birer bölümün yazılı olduğu kağıtlar, Diego Velazquez'in "LasMeninas" adlı tablosu, Picasso'nun "LasMeninas" adlı tablosu, EdouardManet' in "Kırda Öğle Yemeği” tablosu, Pisasso' nun "Kırda Öğle Yemeği" tablosu.

\section{Kazanimlar:}

- Absürd tiyatro kavramlarından yola çıkarak tanımını yapar.

- Absürd tiyatronun özelliklerini ifade eder.

\section{Süreç}

\section{A-Hazırlık- Isınma}

\section{Etkinlik}

Mekanda serbest yürünür. Lider tarafından aşağıdaki kavramlar sırasıyla söylenir, kişiler bu kavramları eş zamanlı olarak bedenleriyle ifade eder. Liderin yönergesiyle 2'li, 3 'lü gruplarla devam edilir.

$\begin{array}{lll}\text { - II. Dünya savaşı } & - \text { Gerçeküstü } & - \text { Hayatın anlamsızlı̆̆1 } \\ \text { - Özgürlük } & - \text { Uyumsuzluk } & - \text { Korku ve güvensizlik } \\ \text { - Us (akıl) dışı } & - \text { Aykırıllk } & - \text { İletişimsizlik } \\ \text { - Yabancılaşma } & - \text { Ölümlü olmak } & \end{array}$

\section{Etkinlik}

İki grup oluşturulur. Gruplara "uyumlu”, “uyumsuz” konuları ve mekân verilir. Verilen bu kavramlardan yola çıkarak sessiz, sözsüz ve hareketsiz oyun hazırlamaları yönergesi verilir.

Etkinlikler üzerine konuşulur.

\section{Etkinlik}

İki grup oluşturulur. Gruplar, karş1lıklı sırt sırta vermiş koridor biçiminde dururlar. Tanımdaki cümleler bölünmüş, her numaradan 2 adet olacak şekilde numaralandırılmış olarak katılımcılara dağıtılır. Aynı numaralı kâğıtlarda birbirinden farklı (bölünmüş) cümleler yazılıdır. Gruplar birbirine arkasını döner; koridor biçiminde dururlar. Lider bir numara söyleyince aynı numara elinde olanlar koridorun içine döner. Kâğıtta yazılı olanı ilk söyleyen grup bir puan alır.

- 1940'ların sonunda boy gösteren,

- $\quad 1950$ 'lerin sonu ile

- 60’Jarın ilk yarısında

- popülaritesi artan

- ve 60'lı yı1ların ikinci yarısından 
- sonra da etkisini yitirmeye başlayan

- II. Dünya savaşı sonrasında ortaya çıkan

- ve yaşamın akla aykırılı̆̆ını,

- bilinen tüm sanatsal uyumları bozarak

- sahneye getiren tiyatro akımina

- “absürd tiyatro" (uyumsuzluk tiyatrosu) denir.

\section{B-Canlandırma}

\section{Etkinlik}

İkili(A,B) gruplar oluşturulur. Küçük kapalı kağıtlara yazılmış olan (itfaiyeci, polis, öğretmen, su tesisatçısı, öğrenci, pazarlamac1, ünlü bir bilim insanı, seks iş̧̧isi, illüzyonist, bankac1, ayakkabı tamircisi, doktor, çilingir, kuaför, eczacı, emlakçı, kasap, dilenci, rejisör, astronot, medyum) mesleklerden katılımcılar birer tane alırlar ve bu kağıtları sağ ellerinde tutarlar. "Balkon" oyununda geçen repliklerin yazılı olduğu kapalı kâğıtları da sol ellerinde tutarlar (Ek 1). Liderin yönergesiyle grup önce sağ elindeki (meslek yazılı olan) kâğıdı sessiz okur ve eş zamanlı doğaçlama başlar. Liderin ikinci yönergesiyle A’lar sol ellerindeki repliği rol içinde söyler(doğaçlama devam eder). Üçüncü yönergeyle B'ler sol ellerindeki repliği rol içinde söyler. Bir süre sonra doğaçlama bitirilir. Gruplar izlenir.

\section{Ara Değerlendirme}

Canlandırmada neler dikkatinizi çekti? Sizce Absürd tiyatronun hangi özelliği vurgulanmıştır?

Diyalogların İlişsisizliği- Olay dizisinin karmaşası özelliğine vurgu yapılır. Absürd tiyatroda diyaloglar, anlamsız ve gayesiz birtakım 'söz salataları' dır. Klasik bir oyunda gözlediğimiz 'başı, gelişimi ve sonu belli' bir oyun yerine, 'rasgele’ bir başlayış ve 'rasgele' bir bitiş var gibidir. Yazarlar, bir öykü anlatmak niyetinde değillerdir.

\section{Etkinlik}

Absürd oyunlardan bazı bölümler verilir (Ek 2) (her gruba aynı durum verilebilir), grupların, başına ve sonuna eklemeler yaparak, kendi istedikleri gibi canlandırmaları söylenir (Kendine özgülük özelliğine vurgu yapılır).

\section{Etkinlik}

4 grup oluşturulur. Her gruba bir resim verilir (Ek 3). Bu resimler sözsüz, sessiz ve hareketsiz canlandırılır. Canlandırmalar arasındaki farklar üzerine konuşulur.

\section{C- Değerlendirme}

\section{Etkinlik}

Herkese birer kâğıt verilir, Absürd tiyatronun tanımını yazınız? Absürd tiyatronun özelliklerini yazın? Soruları sorulur. İkili üçlü gruplar birlikte yazarlar. 
Ömer Çetinkaya \& Ömer Adıgüzel - Yaratıcı Drama Dergisi 2018, 13(1), 1-17 